\title{
Attribution of Library Costs
}

\begin{abstract}
Universities conduct a variety of cost-allocation studies that require the collection and analysis of library-cost data. Cost accounting methods are used in most studies; however, costs are attributed to library user groups in a variety of ways. Cost accounting studies are reviewed and allocation methods discussed. Summary data from the Purdue University Libraries and Audio-Visual Center cost study are presented.
\end{abstract}

$\mathrm{U}$ NIVERSITY ADMINISTRATORS conduct a variety of cost studies aimed at determining the costs of instructional, research, and public service programs. The general purposes of these studies are to (1) examine the allocation of resources; (2) provide information for future budgeting; (3) provide a basis for comparison of similar activities; and (4) provide data for government agencies and associations.

While library services constitute a small portion of university budgets (usually $2-5$ percent), they are an essential part of instructional and research programs. The costs associated with library services, because they are joint or indirect costs, represent a difficult allocation problem for the cost accountant.

This paper will review major library cost accounting studies, examine the methods currently in use to allocate library costs to instructional programs, and present comparative data derived from the application of these methods.

\section{Library Cost Studies}

Cost studies conducted at four major university libraries-Stanford, Columbia, University of California, and Purdue-are relevant to the topic of cost allocation. The Stanford study, con-

Miriam A. Drake is assistant director, administrative services, Purdue University Libraries, West Lafayette, Indiana. ducted in $1964^{1}$ and revised in $1970,{ }^{2}$ was undertaken to determine the allocation of library costs to four major user groups: undergraduates, graduate students, faculty, and staff. Cost elements were developed for each cost center or facility in the library system. Population and circulation data were gathered and applied to costs to determine the cost to be charged to each user group. The total costs for each group were divided by the population to yield per capita cost and cost ratios.

A similar study was conducted by Gerald Quatman at Purdue University in $1961 .^{3}$ The Quatman study was undertaken to provide data on the cost of providing library services for sponsored research programs. The study was unsatisfactory for three reasons: (1) Students and faculty populations were not calculated on the same basis; (2) actual research use could not be measured directly; and (3) the implicit assumption in the study was that "the average graduate student or faculty member engaging in sponsored research used the same amount of library services as the average graduate student or faculty member employed in other university duties."

In 1968-69 Columbia University conducted surveys of use and cost to determine the cost that should be allocated to research. ${ }^{4}$ The allocation was based solely on use and not weighted by population. Analysis of survey data indicated 
that research accounted for 46.9 percent of library use; instruction 31.8 percent; both instruction and research 11.4 percent; and other 9 percent.

The Leimkuhler and Cooper study, conducted at the University of California in 1970, was undertaken to develop a cost-flow model for university libraries. $^{5}$ Cost data were gathered and analyzed for cost centers, both processing and service. The study did not allocate costs to users; however, it did provide useful unit costs, such as cost per unit of circulation, cost per dollar acquisition, etc.

In 1976 the Purdue University Libraries and Audio-Visual Center completed a cost allocation study that was conducted for the purpose of supplying input data for the university's program cost study. ${ }^{6}$ The specific objectives of the project were to determine the costs of providing library and audiovisual services and to allocate these costs to teaching departments and user groups within each department. The allocation methods used, and results, are presented below.

\section{Allocation Methods}

There are four basic methods for attributing the cost of library services to instructional and research programs. The first method uses faculty size as a base (usually on a full-time equivalent (FTE) basis) and divides costs according to the proportion of faculty FTEs in each department. Student enrollment, number of courses offered, number of graduate students, and other variables that are related to library costs are not considered in this method.

The underlying assumptions of this technique are that library usage for any single department or program is proportional to the size of faculty associated with the department and per capita usage is the same for all departments. Circulation data from a cost study of the Purdue University Libraries and
Audio-Visual Center show these assumptions to be false.

For example, the English faculty at Purdue represented 4 percent of the faculty population, but their library loans were 8 percent of loans to all faculty during the sample period. Per capita loans to faculty in the English department were 11.2 , while per capita loans to the civil engineering faculty were $3.7 .{ }^{7}$

The second method of library cost allocation is the standard technique for distribution of indirect costs and is based on faculty salaries. The National Center for Higher Education Management Systems (NCHEMS) recommends that library costs be allocated according to compensation adjusted by faculty activity analysis. ${ }^{8}$ This technique suggests that library usage varies in proportion to the compensation being paid and time spent on various activities. Higher salaried departments carry a higher share of library costs. In addition, the division of library costs between research and instruction, produced by the faculty activity analysis, is proportional to the time spent by faculty members in each activity.

The application of this method does not account for the type of instruction or the type of research being performed by the departments. Humanities departments, where research and instruction rely heavily on library resources, generally provide lower faculty salaries than science and engineering departments, where both teaching and research are more laboratory oriented and less dependent on the library.

NCHEMS also suggests that a library can be costed directly if it is identified with a particular school or college. For example, a library that is associated with a college of business administration would be considered part of that college, with the cost of library services allocated entirely to business administration programs. This method is based 
on intended use, which will be discussed below.

\section{Methods Based on UsE}

The last two methods of library cost allocation are based on usage but differ in their assumptions and applications. One method is based on intended use or direct cost and the other on actual use.

The intended use approach assumes that library materials and services are provided by a university with the intent that they be used by specific groups. While the technique has the advantages of direct costing and relatively simple data gathering, it does not result in an accurate summary of program cost. In earlier days when academic disciplines were purer, books purchased in a subject area were likely to be used almost exclusively by people in that discipline. With the increase in interdisciplinary studies and research, library materials in any one discipline are serving needs of people outside the discipline as well as people who are associated with the particular subject area.

For example, the Purdue Libraries circulation study indicated that 58 percent of the loans made from the Krannert Library, School of Management, were made to faculty and students associated with programs in management or agricultural economics. People in fields other than those served by the library accounted for 42 percent of the loans and included engineers, home economists, pharmacists, and others. ${ }^{9}$

Trends in both research and instruction suggest that interdisciplinary activity is increasing. As a result of this increase, usage patterns in libraries will show more diverse populations using the literature in all fields. It is no longer realistic to assume that economics books will be used exclusively by economists or that use of psychology books will be restricted to psychology majors. A more accurate distribution of library costs will result if actual usage is considered.

The actual use approach of allocating library costs is based on the theory that library services are offered to the total community and that the groups that use them should bear the burden in proportion to their actual usage. The method requires data on the identity of user groups and their use of library services.

While statistics, such as number of reference questions answered and inhouse use of library materials, are useful, they are costly to collect and process. Recorded circulation is the most convenient statistic to collect, and it gives a reasonably accurate estimate of the usage of the library by different user groups. The cost of collecting circulation data in libraries that use manual circulation systems will vary with the type of system being used. Hand tabulation of library use may not be cost justified. Allocation of library costs using the actual use approach, however, does provide a more accurate library cost component for university programs.

\section{RESEARCH COSTS}

Satisfactory methods for allocating library costs between research and instruction in conventional academic libraries have not been developed. When faculty members or graduate students borrow materials from the library, the only way of determining how the material is to be used is to ask. This method was used in the Columbia and Stanford studies discussed above.

The Columbia study concluded that 52.6 percent of library use was attributable to research. The 1970 Stanford study allocated 30.9 percent of library costs to research. The primary drawback of user surveys to determine research or instructional use is that the user may or may not have a specific use in mind when library material is borrowed. When library users borrow books or journals, they may have some specific in- 
structional or research use for the material or they may borrow for background or recreational reading. In addition, library user surveys are expensive and time consuming for both staff and users.

Universities that have large amounts of sponsored research generally use crude techniques for allocating library costs associated with research. One method is based on faculty salaries adjusted by faculty activity analysis. Unfortunately, the method does not produce an accurate measure of the proportion of library resources being spent to support research programs. The method carries the disadvantages of the salary-based technique compounded by the inaccuracies in faculty activity analysis.

\section{Purdue Study}

During the course of the 1974-75 Purdue study, the allocation methods described above were discussed by the study team, librarians, and university administrators. The conclusion was that while the actual use method was most suited to the university's needs, a comparison of results obtained by the four methods would be useful. There was also extensive discussion of appropriate allocation techniques for research and instruction. The study team was unable to devise a satisfactory method for dividing costs between research and instruction; therefore, total costs were allocated without regard to the end uses of library resources.

The Purdue Libraries consist of a central processing department and twenty-four departmental libraries. The intended use computation is based on the costs of purchasing materials and the cost of operating service facilities intended to be used by a department or group of departments. The purchase of library materials at Purdue is controlled through fund numbers assigned to each teaching department. Purchase data were summarized for the fiscal year
1975 for each fund number. The average cost of processing materials was added to the purchase price to produce a total cost of materials for each department. The cost of operating the Physics Library was attributed wholly to the School of Science in the computation of intended use distribution.

The actual use distribution consisted of ascertaining the total cost of operating the libraries and actual usage of materials by user group. The cost of operating the libraries was derived from fiscal and budget documents and included salaries and wages, fringe benefits, space and utilities, equipment, computer expense, and administrative, supplies, and miscellaneous expenses. Data on the identification of users of the libraries were not readily available; therefore, a survey of recorded circulation was undertaken in the twenty-four libraries. The survey was conducted during the three busiest months of the year, February 1 through April 30, 1975. The results of the survey provided the data needed to allocate costs on the basis of usage.

\section{Results}

Table 1 shows the allocation of library costs to major user groups with comparative data from the 1961 Purdue study and two Stanford studies.

The differences between Purdue and Stanford allocations are based, in part, on differences in relative enrollment and cost components. The higher percentages in the category of "other" for Purdue reflect the inclusion of staff in that group and greater use of the libraries by the public.

Table 2 summarizes the distribution of costs to teaching departments obtained through the application of four allocation methods. The differences between faculty FTE and faculty salary distribution generally are small. The greatest difference occurs in engineering where the faculty salary distribution is 
TABLE 1

Distribution of Costs to Major Groups

\begin{tabular}{lcccr}
\hline \hline & \multicolumn{4}{c}{ Percent of Total Cost } \\
User Level & 1961 & $\begin{array}{c}1965 \\
\text { Stanfor }\end{array}$ & 1975 \\
\hline Undergraduates & 40.8 & 15.4 & 24.6 & Purdue \\
Graduate Students & 36.0 & 43.7 & 37.4 & 43.9 \\
Faculty & 15.7 & 36.4 & 33.8 & 9.5 \\
Other & 7.5 & 4.5 & 4.2 & 9.9 \\
\hline
\end{tabular}

- Distribution of usage.

$\dagger$ Stanford data include staff. Purdue staff included in other.

2.3 percent greater than the faculty FTE distribution.

More significant differences occur in the comparison of cost distribution between teaching faculty salaries and intended use. The intended use method indicates that the School of Humanities, Social Science, and Education share of cost is 41.4 percent, compared with 24 percent using the method based on teaching faculty salaries. The share of the School of Agriculture indicates a 9.5 percent difference, and Engineering shows an 8.8 percent difference when faculty salaries and intended use are compared. The distribution of faculty salaries is a function of both the number and average salary of faculty members in the various schools. The average salary of teaching faculty in humanities, social science, and education is lower than the average salary in agriculture or engineering; however, the proportion of library materials and facilities that are provided for humanities, social science, and education are far greater than those provided for agriculture or engineering.

The differences between the distributions based on intended use and actual use are generally smaller than the differences between faculty salaries and intended use. The greatest difference occurs in home economics in which intended use produces 1.9 percent share of costs and actual use indicates 8.9 percent. This difference reflects the smaller share of library budget that is allocated to the home economics library and materials and the diversity and interdisciplinary nature of the school's programs. The library materials needed by stu-

TABLE 2

Purdue University Libraries and Audio-Visual Center Distribution of Libraries' Cost By School, 1974-1975

\begin{tabular}{|c|c|c|c|c|}
\hline School & $\begin{array}{l}\text { Teaching } \\
\text { Faculty FTE }\end{array}$ & $\begin{array}{l}\text { Percent of Librari } \\
\text { Teaching } \\
\text { Faculty Salaries }\end{array}$ & $\begin{array}{l}\text { st Allocated by } \\
\text { Intended Use }\end{array}$ & Actual Use \\
\hline Agriculture & 17.5 & 16.4 & 6.9 & 9.8 \\
\hline Engineering & 17.1 & 19.4 & 11.7 & 14.1 \\
\hline Home Economics & 3.1 & 2.7 & 1.9 & 8.9 \\
\hline \multicolumn{5}{|l|}{ Humanities, Social } \\
\hline Science, \& Education & 25.1 & 24.0 & 41.4 & 38.7 \\
\hline Management & 3.7 & 4.3 & 8.6 & 6.2 \\
\hline Pharmacy & 3.8 & 3.6 & 4.1 & 1.9 \\
\hline Science & 20.8 & 22.0 & 17.9 & 16.3 \\
\hline Technology & 5.5 & 4.2 & 3.0 & 3.0 \\
\hline Veterinary Medicine & 3.4 & 3.4 & 4.5 & 1.1 \\
\hline TOTAL & 100.0 & 100.0 & 100.0 & 100.0 \\
\hline
\end{tabular}


dents and faculty in home economics are found in a variety of disciplines, including agriculture, creative arts, education, and management.

\section{ConcLusion}

The choice of a library cost allocation method will depend primarily on four factors: (1) the size of the library budget relative to the university's total budget, (2) diversity of instructional programs, (3) availability of data, and (4) philosophy of university management.

In small colleges where educational programs are limited, allocations on the basis of faculty salaries or FTE's may be satisfactory. These allocations meth- ods also would be acceptable in cases where the library budget is relatively small or management is willing to have some instructional programs subsidize others.

In universities that offer a greater number and diversity of instructional programs and engage in sponsored research, usage-based allocation methods will give a more accurate accounting for the allocation of library costs. While the actual usage methodology is preferred, it may not be possible to implement because of the lack of usage data and the difficulty of data collection. When usage data are not available, intended use will give a reasonably reliable estimate.

\section{REFERENCES}

1. Glen Densmore and Charles Bourne, A Cost Analysis and Utilization Study of the Stanford University Library System (SRI Project IM-5012; Stanford, Calif.: Stanford University Libraries, 1965).

2. "A Cost and Utilization Analysis of the Stanford University Libraries System," unpublished, 1970.

3. Gerald L. Quatman, The Costs of Providing Library Services to Groups in the Purdue University Community-1961 (Lafayette, Ind.: Purdue University Libraries, 1962).

4. Ellis Mount and Paul Fasana, "An Approach to the Measurement of Use and Cost of a Large Academic Research Library System: A Report of a Study Done at Columbia University Libraries," College \& Research Libraries 33:199-211 (May 1972).

5. Ferdinand Leimkuhler and Michael D. Coo- per, Cost Accounting and Analysis for University Libraries (Berkeley, Calif.: Office of the Vice President Planning and Analysis, University of California, 1970).

6. Miriam A. Drake, Libraries and Audio-Visual Center Cost Allocation Study (RDU 7602; West Lafayette, Ind.: Purdue University Libraries and Audio-Visual Center, 1976). Available as ERIC document, ED 125566.

7. Miriam A. Drake, Circulation of Materials in Purdue University Libraries (RDU 75-06; West Lafayette, Ind.: Purdue University Libraries and Audio-Visual Center, 1975).

8. James R. Topping, Cost Analysis Manual (Field Review Edition, Technical Report no. 45; Boulder, Colo.: National Center for Higher Education Management Systems, 1973), p.159.

9. Drake, Circulation of Materials. 


\section{NEW Up-To-Date Books From Noyes Data}

HARDCOVER BOOKS-LATE 1977

AUTOMOTIVE POLLUTION CONTROL CATALYSTS AND DEVICES by M. Sittig: A review of the affordable technology. The adoption of certain of these technical alternatives has occurred already and others will be introduced soon. Mandated fuel economy goals will require that fuel economy become a high priority design constraint. This is therefore an opportune time to survey the practical aspects of catalysts, hardware and control devices. ISBN 0-8155-0678-3; \$39

EPOXY RESINS AND PRODUCTS-RECENT ADVANCES by M. W. Ranney: Describes significant recent technological advances. The largest user of epoxy resins is perhaps the protective coatings industry. Nowhere else is the impact of ecological considerations more evident as powder, photocurable, electrodeposited and high solids coating systems, using little organic solvent, are being commercialized rapidly. ISBN 0-8155-0679-1; \$39

OFFSHORE AND UNDERGROUND POWER PLANTS edited by R. Noyes: Uncontroversial plant sites for generating electric power by any means are becoming increasingly scarce. Consequently, utility companies are looking out to sea or beneath the surface of the earth for suitable power plant locations. This is a most exhaustive and detailed treatise on this timely subject, based on government-sponsored reports. ISBN 0-8155-0680-5; \$42.

TEXTURED PROTEIN PRODUCTS by M. Gutcho: There is a major effort in the world today to produce nutritious, high protein, meat-like products of other than animal origin, suitable for human consumption. They are made from vegetable proteins processed primarily by wet fiber spinning and thermoplastic extrusion. A large variety of new, innovative methods are described in this book. ISBN 0-8155-0681-3; \$39

YEASTS FOR FOOD AND OTHER PURPOSES by J. C. Johnson: Yeasts can proliferate without sunlight, yet they contain many valuable nutrients including proteins, fats, minerals and B-complex vitamins. The bulk of the single cell yeast protein is in the form of enzymes and is a valuable source of them or of nutritional single cell protein. Over 160 production and use processes are described. ISBN 0-8155-0682-1; \$36

PARTICIPATIVE MANAGEMENT-QUALITY OF WORKLIFE AND JOB ENRICHMENT edited bY R. B. Miller: This is a book about management systems where everyone profits directly from increased productivity. Imparts detailed knowledge of the mechanics of such a system and the problems likely to arise. ISBN 0-8155-0683-X; $\$ 18$

RADIOACTIVE WASTE DISPOSAL-LOW AND HIGH LEVEL edited by W. R. Gilmore: Based on federally funded studies, this book is concerned with the technological aspects of processing and storing both high level and low level radioactive wastes (radwastes). Detailed accounts are given of radwaste storage and disposal at government-operated and commercial nuclear facilities. ISBN 0-8155-0684-8; $\$ 39$

PHYSICAL DISTRIBUTION MANAGEMENT-ANALYTICAL APPROACH TO CUTTING COSTS bY R. Willis: Distribution of most merchandise requires freight transportation, warehousing, materials handling, protective packaging, inventory control, order processing, demand forecasting and customer service. This book provides simple analytical techniques that can be used gainfully by the modern distribution executive. ISBN 0-8155-0658-5; \$18

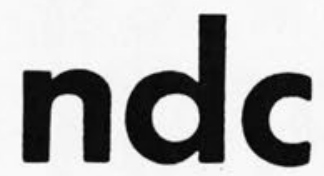

